\title{
RESISTANCE TO CHANGE MAHASISWA PSIKOLOGI UNIVERSITAS ESA UNGGUL YANG MENGIKUTI PERKULIAHAN ONLINE
}

\author{
Sulis Mariyanti, Mariyana Widiastuti \\ Fakultas Psikologi Universitas Esa Unggul \\ Jalan Arjuna Utara No.9 Tol Tomang Kebon Jeruk, Jakarta Barat - 11510 \\ sulis.mariyanti@esaunggul.ac.id
}

\begin{abstract}
With increasingly sophisticated internet technology, several educational institutions including the Universitas Esa Unggul began to adjust to developing online learning patterns that were considered more effective and efficient, not only for lecturers but also for students. Changes in learning patterns from conventional ones using full face-to-face changes to learning patterns that use distance learning or what is known as online learning seem to reap a variety of responses and attitudes from psychology students who take online lecture material to a maximum of 3 online lecture material in each semester. Every change will be followed by inconvenience so that there are those who are not supportive and reject the change or known as resistance to change, but there are also students who feel fortunate in implementing online lectures. The purpose of this study is to determine the profile of resistance to change psychology students who take online lectures. This research is a descriptive quantitative study with a sample of 87 UEU psychology students who have attended a one-semester face-to-face and online lecture. The Resistance to Change (RTC) scale was arranged based on the reference from Oreg (2008) with 42 valid items and a reliability value of 0.97. The results showed that more psychology students had lower RTC (61\%) or more who accepted the change in conventional learning patterns to become online. Students with low RTC are those who are working, not married, and are male.
\end{abstract}

Keywords: Resistance to Change, Online Learning, Psychology Students

\begin{abstract}
Abstrak
Teknologi internet yang semakin canggih, beberapa institusi pendidikan termasuk Universitas Esa Unggul mulai menyesuaikan diri dengan mengembangkan pola pembelajaran online/daring yang dinilai lebih efektif dan efisien, tidak hanya bagi dosen tetapi juga bagi para mahasiswa. Perubahan pola pembelajaran dari yang konvensional dengan menggunakan tatap muka penuh berganti dengan pola pembelajaran yang menggunakan pembelajaran jarak jauh atau yang dikenal dengan pembelajaran online tampaknya menuai beragam respon maupun sikap dari para mahasis wa psikologi yang mengikuti materi kuliah online maksimal 3 materi kuliah online di setiap semester. Setiap perubahan akan diikuti oleh ketidaknyamanan sehingga ada yang bersikap tidak mendukung dan menolak perubahan atau dikenal dengan istilah resistance to change, namun ada pula mahasis wa yang merasa beruntung dengan diterapkannya perkuliahan online. Tujuan penelitian ini yaitu mengetahui profil resistance to change mahasiswa psikologi yang mengikuti perkuliahan online. Penelitian ini merupakan penelitian kuantitatif deskriptif dengan sampel 87 mahasiswa psikologi UEU yang pernah mengikuti perkuliahan tatap muka dan online minimum satu semester. Skala Resistance To Change (RTC) disusun berdasarkan acuan dari Oreg (2008) dengan 42 item valid dan nilai reliabilitas 0,97. Hasil penelitian menunjukkan lebih banyak mahasiswa psikologi yang rendah RTC nya (61\%) atau lebih banyak yang menerima perubahan pola pembelajaran konvensional menjadi online. Mahasiswa yang rendah RTC nya adalah yang berstatus bekerja, belum menikah, berjenis kelamin laki-laki.
\end{abstract}

Kata kunci: Resistance to Change, Pola Belajar Online, Mahasiswa Psikologi

\section{Pendahuluan}

Kemajuan teknologi digitalisasi yang semakin pesat menuntut adanya perubahan di berbagai sektor kehidupan, baik di sektor kesehatan, pemerintahan, bisnis, dan lain-lain termasuk bidang pendidikan. Bidang pendidikan di Indonesia, sebelum tahun 2000 pembelajaran hanya dilakukan secara konvensional yaitu dengan pertemuan tatap muka di ruang-ruang kelas. Dosen memberikan informasi, penjelasan, tanya jawab, memperagakan alat serta contoh-contoh praktis dan mahasiswa akan melihat, mendengarkan dan mencatat yang semuanya dilakukan di kelas. Akan tetapi dengan adanya berbagai keterbatasan dan kendala seperti kapasitas ruangan, kemacetan, jarak tempuh yang jauh, pekerjaan, dan berbagai aktivitas la in yang harus dilakukan di luar kampus pada akhirnya memberikan peluang perubahan untuk 
mengembangkan pola pembelajaran baru yang memanfaatkan media internet.

Berkembangnya teknologi internet yang semakin canggih ini membuat beberapa institusi pendidikan mulai menyesuaikan diri dengan mengembangkan pola pembelajaran e-learning (online) yang dinilai lebih efektif dan efisien tidak hanya bagi dosen tetapi juga bagi para mahasiswa. Perubahan pada pola pembelajaran dari yang konvensional dengan menggunakan tatap muka penuh berganti dengan pola pembelajaran yang tidak hanya menggunakan tatap muka di kelas tetapi juga dengan menggunakan proses pembelajaran jarak jauh atau yang dikenal dengan pembelajaran daring. Menurut Allen (dalam Khoirunnisa, Dewi, \& Nurwidawati, 2018) pembe lajaran online merupakan pola pembelajaran yang didisain dengan memanfaatkan sistem komputer sehingga mampu mendukung proses pembelajaran. Bahkan pemerintah pun telah berkomitmen untuk meningkatkan pemerataan akses dan kualitas pembelajaran di Perguruan Tinggi di Indonesia dengan menciptakan sistem pembelajaran daring (SPADA). Seiring dengan program yang dicanangkan tersebut, maka beberapa Universitas Negeri dan Swasta di Indonesia mulai menerapkan sistem pembelajaran daring dan salah satunya adalah Universitas Esa Unggul.

Universitas Esa Unggul telah menerapkan pola pembelajaran online sejak tahun 2006 pada mahasiswa kelas paralel dengan sistem 8-6 yang artinya 8 (delapan) kali tatap muka di kelas dan 6 (enam) kali pembelajaran melalui online. Seiring dengan semakin canggihnya perkembangan sistem daring dan adanya dukungan kebijakan pemerintah untuk menerapkan pola pembelajaran daring, maka Universitas Esa Unggul pun menetapkan kebijakan baru untuk memperpanjang waktu belajar daring menjadi full online untuk maksimum 3(tiga) hingga 4 (empat) materi kuliah per semesternya dari 7-8 mata kuliah per semesternya. Hanya untuk UTS serta UAS saja yang tidak online. Dari sistem pembelajaran online ini, maka setiap mahasiswa diwajibkan membaca modul kuliah dan power point materi kuliah yang telah diunggah oleh dosen, melihat video minimal 20 menit yang berisikan penjelasan singkat tentang materi kuliah, mengerjakan 1 kuis per mata kuliah dan tugas untuk setiap minggunya. Beberapa mahasiswa yang mengambil kuliah online lebih dari 1 (satu) atau 2 (dua) mata kuliah online, maka mereka harus meluangkan waktu yang lebih panjang untuk melihat, membaca dan memahami lebih dari 1(satu) modul kuliah, video, kuis dan tugas-tugas di setiap minggunya.
Perubahan pola pembelajaran full tatap muka dan online dari $8-6$ yang relatif lebih sederhana ke pola pembelajaran full online di Universitas Esa Unggul menuai beragam tanggapan, sikap, keluhan namun juga apresiasi dari para mahasiswa yang mengambil materi kuliah online. Hal itu sejalan dengan penelitian Reagan (2013) yang menunjukkan munculnya perasaan frustrasi yang terkait dengan dengan belajar online. Akan tetapi, dengan adanya perubahan tersebut juga memunculkan perasaan gembira dan senang yang dialami terkait dengan kemampuannya untuk menyelesaikan tuntutan belajar online. Artinya, dapat disimpulkan bahwa adanya perubahan pola pembelajaran yang diterapkan bisa memunculkan sikap yang berbeda-beda. Ada yang positif, senang, antusias, optimis dan juga ada yang bersikap negatif, mengeluh, menolak atau resistance, merasa berat, dan terbebani.

Setiap perubahan akan diikuti oleh ketidaknyamanan sehingga ada yang bersikap tidak mendukung perubahan atau dikenal dengan istilah resistance to change. Piderit (2000) menyatakan bahwa konsep resistance to change merupakan sebuah konstruk yang memiliki banyak dimensi, integrasi dari kognitif, afektif dan perilaku yang dapat mempengaruhi respon seseorang dalam menghadapi perubahan. Resistance to change (RTC) menurut Oreg (2008) adalah kecenderungan sesorang untuk bertahan atau menolak perubahan, tidak menghargai perubahan, menunjukkan sikap permusuhan dengan berbagai konteks. Seseorang yang mengalami RTC menunjukkan menunjukkan sikap tidak ingin meninggalkan cara-cara konvensional, tidak memiliki keinginan untuk belajar sesuatu yang baru sehingga menyulitkan untuk menjalani perubahan yang terjadi.

Perubahan pola pembelajaran dari pola variasi tatap muka dan online 8-6 ke pola pembelajaran full online yang ditetapkan oleh Universitas Esa Unggul idealnya memberikan dampak positif kepada dosen maupun kepada mahasiswa. Melalui pembelajaran pola full online ini mahasiswa akan memiliki waktu yang lebih banyak untuk melakukan aktivitas bekerja, belajar, melakukan hobinya atau aktivitas sosial lainnya karena tidak harus datang tatap muka setiap hari, bahan belajar sudah disiapkan secara online sebelumnya sehingga bisa diakses oleh siapapun, dimanapun dan kapanpun, tetap bisa memenuhi kewajiban mengikuti kuliah tanpa ada kekhawatiran macet dan tidak tepat waktu. Namun demikian, ada beberapa mahasiswa yang berkesempatan diwawancara menyatakan berat dan mengeluh dengan kuliah full online karena merasa terbebani 
dengan tugas-tugas yang menumpuk di setiap minggunya, tidak memahami secara maksimal tentang isi modul dan power point materi yang telah diunggah karena tidak ada kesempatan langsung bertanya saat dibutuhkan, serta kejenuhan hanya bisa bertatap muka dengan materi tanpa bisa bertemu langsung dosen dan teman-teman kuliahnya. Sebaliknya ada beberapa mahasiswa yang sangat antusias, senang, merasa beruntung dan menikmati saat mengikuti kuliah online, karena banyak ide yang bisa dituliskan, merasa lebih efisien dan yang pasti tidak harus menghadapi kemacetan setiap hari untuk pergi ke kampus. Hal ini sejalan dengan penelitian Nindyati (2009) yang menyatakan bahwa RTC berpengaruh terhadap perilaku inovatif. Selain itu, penelitian yang lain menyatakan bahwa RTC berpengaruh terhadap kepuasan kerja (Naomi \& Nindyati, 2007). Berdasarkan uraian tersebut di atas, dapat disimpulkan bahwa adanya resistance to change dapat berpengaruh pada perilaku inovasi serta kepuasan kerja. Mereka yang resistance terhadap perubahan akan lebih banyak mengeluh, tidak merasa enjoy melaksanakan aktivitasnya, dan Tabel 1 sulit untuk menemukan ide-ide baru karena terpaku oleh pola-pola kebiasaan lama. Tujuan dari penelitian ini yaitu mengetahui profil dan gambaran resistance to change mahasiswa Psikologi Universitas Esa Unggul yang mengikuti kuliah online.

\section{Metode Penelitian}

Penelitian ini merupakan penelitian kuantitatif deskriptif dengan teknik purposive sampling diperoleh sampel 87 mahasiswa Psikologi UEU yang pernah mengikuti perkuliahan tatap muka dan mengikuti perkuliahan online untuk 3-4 matakuliah online dalam satu semester. Alat ukur Resistance To Change (RTC) disusun berdasarkan acuan dari Oreg (2008) dengan 42 item valid dan nilai reliabilitas 0,97 yang menggali Routine Seeking, Emotional Reaction To Impose Change, Cognitive Rigidity, dan Short Term Focus dan berikut contoh itemnya.

Contoh Item

\begin{tabular}{lll}
\hline \multicolumn{1}{c}{ Dimensi } & \multicolumn{1}{c}{ Contoh item } \\
\hline Routine Seeking & - & $\begin{array}{l}\text { Saya lebih mudah memahami materi saat tatap muka } \\
\text { daripada online. }\end{array}$ \\
& - & Tuntutan untuk mengikuti kuliah online saya rasakan sangat \\
Emotional Reaction & & magebani. \\
to Impose Change & - & $\begin{array}{l}\text { Bagi saya, hanya dengan pertemuan tatap muka semua } \\
\text { materi kuliah bisa terserap. }\end{array}$ \\
Cognitive Rigidity & - & $\begin{array}{l}\text { Perubahan perkuliahan menjadi online merepotkan rencana } \\
\text { belajar saya. }\end{array}$
\end{tabular}

Short Term Focus

\section{Hasil dan Pembahasan \\ Gambaran Umum Subjek}

Penelitian ini melibatkan 87 mahasiswa Psikologi di kelas paralel Universitas Esa Unggul yang pernah dan sedang mengambil kuliah online dari angkatan 2019, 2018, 2017, 2016 dan 2015. Berdasarkan hasil diperoleh dapat dilihat bahwa jumlah mahasiswa perempuan dalam penelitian ini sebanyak 70\% (61 mahasiswa) dan mahasiswa lakilaki sebanyak 30\% (28 mahasiswa). Dari sejumlah subjek penelitian mayoritas berstatus single yaitu 89,6\% (78 mahasiswa) dan yang telah menikah sebanyak 10,4\% (9 mahasiswa). Dan yang terakhir, mahasiswa yang kuliah sambil bekerja berjumlah $84 \% \quad$ (73 mahasiswa), sedangkan $16 \% \quad(14$ mahasiswa) hanya menjalani kuliah saja.

\section{Gambaran Resistance To Change}

Hasil kategorisasi data resistance to change (RTC) mahasiswa psikologi kelas paralel yang mengikuti kuliah online dapat dilihat pada tabel 1

Tabel 2

Kategorisasi Tingkat RTC

\begin{tabular}{|c|c|c|c|}
\hline $\begin{array}{c}\text { Batasan } \\
\text { Skor }\end{array}$ & $\begin{array}{c}\text { Katego- } \\
\text { risasi } \\
\text { RTC }\end{array}$ & Jumlah & Presentase \\
\hline $\begin{array}{c}X \geq \\
113,72\end{array}$ & Tinggi & 34 & $39 \%$ \\
\hline $\begin{array}{c}X<113, \\
72\end{array}$ & Rendah & 53 & $61 \%$ \\
\hline & Total & 87 & $100 \%$ \\
\hline
\end{tabular}


Dari tabel 2 terlihat bahwa mahasiswa psikologi yang menjalani kuliah online lebih banyak (61\%) yang rendah resistance to change atau menerima perubahan. Artinya meskipun mahasiswa tersebut awalnya terbiasa dan rutin menjalani metode perkuliahan konvensional tatap muka di kelas yang bertemu dan mendengarkan penjelasan materi lansung dari dosen, berdiskusi maupun mendapatkan feedback langsung dari dosen maupun rekan mahasiswa di kelas, tetapi mereka relatif tidak merasakan hambatan, beban saat dituntut menjalani kuliah dengan metode pembelajaran online. Perubahan metode pembelajaran dari tatap muka menjadi online tidak dirasakan sebagai tuntutan yang membingungkan, menyulitkan, tidak menyenangkan, atau tidak nyaman oleh sebagian besar mahasiswa Psikologi yang ada di kelas paralel ini. Mahasiswa merasa siap dengan perubahan sistem pembelajaran dan menilai sistem pembelajaran baru yang diterapkan akan lebih efisien dan menguntungkan. Mahasiswa dengan resistance rendah cenderung menyenangi perubahan, sehingga ketika mereka dituntut untuk mengubah rutinitas atau kebiasaan mengikuti metode perkuliahan lama dengan yang baru cenderung bersemangat, nyaman dan menikmati perubahan. Mahasiswa dengan resistance rendah cenderung melihat perubahan sebagai sesuatu yang positif dan menilai akan memberikan manfaat yang panjang (long term focus) misalnya dalam bentuk bertambahnya wawasan pengetahuan dan pengalaman dengan segala hal yang baru.

Kondisi demikian dapat diduga karena sebagian besar mahasiswa Psikologi UEU di kelas paralel yang menjadi subjek penelitian ini berada pada rentang usia 20 - 35 tahun yaitu mereka yang lahir pada tahun 1980-2000an atau yang disebut sebagai generasi millenial. Mereka adalah generasi digital yang mahir mengakses berbagai sumber informasi apa pun yang dibutuhkan melalui teknologi informasi dengan gadget atau smarthphone. Bahkan dapat dikatakan pada kelompok generasi millenial ini cenderung mengandalkan gadget atau smartphone untuk menjelajahi dunia dan memenuhi kebutuhannya. Kondisi keterpaparan teknologi informasi yang tinggi ini akan memudahkan sebagian besar mahasiswa Psikologi paralel yang sebagian besar adalah generasi millenial ini untuk mengikuti perkuliahan online tanpa mengalami hambatan yang berarti. Mereka tetap enjoy menjalani perubahan metode perkuliahan konvensional tatap muka menjadi online dan tidak menolak perubahan tersebut. Hal ini juga dinyatakan oleh Heather Stanley (dalam Putri \& Handoyo, 2014) dalam disertasi tahun 2007 yang berjudul "Differences in Resistance to Change Between Generations in The Workplace" yang memberikan penjelasan tentang resistance to change di empat generasi yang berbeda yaitu silent generation, baby boomers, generasi $\mathrm{X}$ dan generasi Y. Penelitian tersebut menunjukkan bahwa ada perbedaan signif ikan generasi ke generasi dalam menghadapi perubahan. Dinyatakan bahwa silent generation merupakan generasi yang paling sulit untuk diajak berubah, generasi baby boomers telah menunjukkan adanya sedikit kemauan untuk berubah, generasi $\mathrm{X}$ merupakan generasi yang disebut inovator yaitu generasi yang suka memprakarsai perubahan. Terakhir generasi $\mathrm{Y}$ atau millenials adalah generasi yang mampu merespon perubahan dengan baik (Putri \& Handoyo, 2014).

\section{Resistance To Change Berdasarkan Status Pekerjaan}

Tabel 3

Kategorisasi RTC Berdasarkan Status Pekerjaan

\begin{tabular}{ccc}
\hline Kategorisasi RTC & Bekerja & Tidak Bekerja \\
\hline Tinggi & $28(38 \%)$ & $6(43 \%)$ \\
Rendah & $45(62 \%)$ & $8(57 \%)$ \\
\hline Total & $73(100 \%)$ & $14(100 \%)$ \\
\hline
\end{tabular}

Mahasiswa Psikologi UEU di kelas paralel yang berstatus bekerja dan menjalani kuliah online cenderung lebih banyak yang rendah resistance to change (62\%). Sebagai mahasiswa yang berada pada rentang usia millenial (20-35 tahun) sekaligus juga bekerja menghadapi tantangan akan kehadiran teknologi informasi yang semakin masif. Kondisi perkembangan teknologi informasi semakin maju ini, mahasiswa yang bekerja sambil kuliah bisa dengan mudah membaca materi kuliah, mengunduh materi, mengerjakan tugas kuliah me lalui gawai atau smartphone dimanapun dan kapan pun tanpa mengganggu aktivitas pekerjaan di kantor. Artinya dengan penerapan metode perkuliahan online ini dirasakan menguntungkan karena tidak harus datang kuliah ke kampus, tetapi tetap bisa kuliah dan membaca materi melalui teknologi informasi yang bisa di akses dimanapun. Hasil studi dari Boston Consulting Group \& University of Berkley pada tahun 2011 menyatakan bahwa minat membaca secara konvensional saat ini sudah menurun karena generasi millenial lebih memilih membaca melalui smartphone.

Dengan demikian adanya perubahan metode perkuliahan yang diterapkan oleh Universitas Esa Unggul dari yang konvensional tatap muka menjadi online bukanlah hambatan. Bahkan mahasiswa Psikologi di kelas paralel ini sudah terbiasa, terlatih 
dan "dekat" dengan media sosial yang sangat memungkinkan bisa menjalankan perannya sebagai mahasiswa dan sekaligus pekerja dengan lebih optimal. Mahasiswa yang bekerja merasa bersyukur dengan tuntutan kuliah online yang membuat mereka lebih fleksibel menyusun prioritas antara tugas kuliah dan tugas kantor, lebih efisien, dan tidak banyak menguras energi fisik seperti saat kuliah tatap muka. Hal ini sejalan dengan hasil penelitian yang dilakukan oleh Bradutanu (2012) dengan judul "Identifying the reducing resistance to change phase in an organizational change model" yang mengatakan bahwa setelah karyawan mengetahui keuntungan dari perubahan yang baru, banyak dari karyawan menjadi lebih terbuka dan bersedia berpartisipasi dalam proses perubahan tersebut. Demikian pula dengan mahasiswa psikologi dengan status tidak bekerja atau hanya full kuliah, juga rendah RTC nya (57\%). Mereka memiliki lebih banyak waktu untuk berfokus pada kegiatan akademik yang menguntungkan yaitu dengan mengakses materi kuliah via online tanpa dibebani oleh tuntutan pekerjaan.

\section{Resistance To Change Berdasarkan Jenis Kelamin}

Tabel 4

Kategorisasi RTC Berdasarkan Jenis Kelamin

\begin{tabular}{ccc}
\hline Kategorisasi RTC & $\begin{array}{c}\text { Mahasiswa laki- } \\
\text { laki }\end{array}$ & $\begin{array}{c}\text { Mahasiswa } \\
\text { Perempuan }\end{array}$ \\
\hline Tinggi & $8(29 \%)$ & $29(48 \%)$ \\
Rendah & $20(71 \%)$ & $32(52 \%)$ \\
\hline Total & $28(100 \%)$ & $61(100 \%)$ \\
\hline
\end{tabular}

Pada dasarnya setiap perubahan menuntut adanya kemampuan penyesuaian diri. Ketakutan yang berlebihan dan rasa terancam berlebihan dalam menghadapi perubahan akan memicu penolakan terhadap perubahan (Robbin \& Judge, 2008). Akan tetapi hal itu tidak terjadi pada mahasiswa laki-laki maupun perempuan fakultas Psikologi di kelas paralel yang harus menjalani perubahan kuliah tatap muka menjadi online. Baik mahasiswa laki-laki maupun perempuan memiliki kecenderungan yang sama yaitu lebih banyak yang rendah RTC-nya. Artinya, mereka lebih banyak yang dapat menerima perubahan metode perkuliahan yang diterapkan oleh kampus UEU. Kondisi itu dapat diduga karena mahasiswa psikologi lebih banyak yang berada pada kelompok generasi millenial ini telah terkondisikan (conditioning) oleh situasi sosial dimana hampir semua anggota masyarakat saat ini telah memiliki smartphone sebagai media untuk berkomunikasi, mencari informasi maupun memenuhi kebutuhannya. Hasil survei bertajuk Indonesia
Millenial Report 2019 menunjukkan bahwa 94,4\% millenial Indonesia telah terkoneksi internet (Utomo, 2019). Artinya, baik mahasiswa baik laki-laki maupun perempuan sudah terbiasa dengan segala informasi yang diperoleh dari dunia maya, sehingga tidak merasa bermasalah dan kesulitan dengan penyesuaian dirinya terhadap perubahan metode pembelajaran yang baru. Mereka cenderung bisa fleksibel, sekalipun mereka menemui hambatan, tidak merasa terbebani dengan tuntutan perubahan dan tetap nyaman dengan perubahan yang diterapkan di kampus UEU.

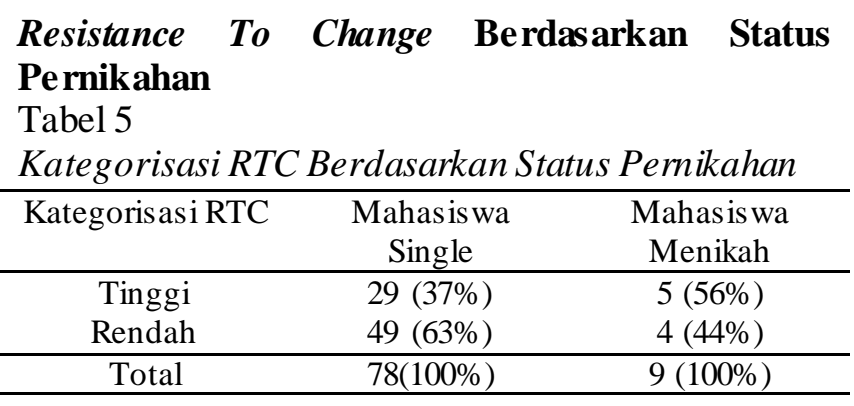

Mahasiswa yang sedang menjalani kuliah dan berstatus single (belum menikah) lebih banyak yang rendah resistensinya terhadap perubahan metode pembelajaran dari tatap muka menjadi online (63\%). Sedangkan mahasiswa yang menjalani kuliah dan telah menikah cenderung lebih banyak yang tinggi resistensinya terhadap perubahan metode pembelajaran (56\%). Hal ini dapat dipahami bahwa setiap perubahan akan dirasakan stressfull dan menuntut adanya penyesuaian diri dan coping untuk menghadapi perubahan itu sendiri. Setiap perubahan juga dapat menimbulkan "kegalauan" emosional karena perubahan selalu menuntut perubahan kebiasaan (habit) yang biasanya disertai oleh perasaan tidak aman, ketakutan, khawatir, ketidaksiapan, dan menilai akan ada kelemahan dari setiap perubahan (Robbin \& Judge, 2008). Perubahan metode pembelajaran dari tatap muka menjadi online bagi mahasiswa yang masih berstatus single (belum menikah) dirasakan tidak memberatkan, karena mereka memiliki waktu yang relatif banyak dan fleksibel untuk melatih ketrampilan online kapanpun dan dan dimanapun. Selain itu, mereka juga tidak banyak menghadapi tuntutan yang beragam kecuali tuntutan kuliah. Hal itu memudahkannya untuk menyesuaikan diri dengan perubahan sehingga tetap merasakan keseimbangan, menerima perubahan sebagai suatu kemajuan dan tidak merasakan beban tekanan yang dapat mengganggu aktivitas kehidupan lainnya (Gunarsa, 2004). 
Sedangkan mahasiswa Psikologi di kelas paralel yang telah menikah lebih banyak yang tinggi RTC nya (56\%) terhadap perubahan metode pembelajaran tatap muka menjadi online. Kondisi demikian dapat diduga karena mahasiswa yang telah menikah memiliki tanggung jawab ganda. Mereka tidak hanya dituntut untuk bertanggung jawab secara akademik, namun juga tanggung jawab keluarga, dan finansial. Banyaknya tuntutan dan alasan keterbatasan waktu yang dialami mahasiswa yang telah menikah dapat memunculkan konflik (work family conflict). Dari hasil penelitian Wulandari dan Dwiyanti (2014) menyatakan bahwa "ada hubungan yang signifikan antara konflik peran ganda dan stress kerja pada perawat wanita yang sudah menikah di RSUD Banyumas". Mahasiswa yang telah menikah harus memilih tuntutan manakah yang menjadi prioritas untuk dise lesaikan terlebih dahulu. Menghadapi kondisi tanggung jawab peran yang relatif beragam, maka mahasiswa yang telah menikah memiliki kecenderungan merasakan stress, terbebani dengan perubahan habit perkuliahan hingga pada akhirnya mengembangkan pola berpikir yang negatif yang pada akhirnya cenderung menghambatnya untuk mengembangkan perilaku yang tidak menerima perubahan seperti enggan mempelajari bagaimana mengakses materi secara online, menarik diri atau tidak mau bertanya kepada mahasiswa lain yang sudah terampil mengakses materi kuliah, tugas merasa bahwa kuliah online itu menyulitkan dan berbagai pandangan negatif lainnya yang menggambarkan penolakan terhadap perubahan.

\section{Simpulan}

Dari hasil penelitian yang melibatkan 87 mahasiswa psikologi UEU yang pernah mengikuti perkuliahan tatap muka dan mengambil maksimal 3-4 mata kuliah online per semester dapat disimpulkan bahwa lebih banyak mahasiswa psikologi yang memiliki resistance to change rendah (61\%). Artinya lebih banyak mahasiswa yang merasakan senang dengan perubahan tersebut dan menilai metode pembelajaran online lebih efisien dan menguntungkan. Mahasiswa yang memiliki resistance rendah terhadap perubahan metode pembelajaran yang diterapkan di Universitas Esa Unggul cenderung lebih banyak yang berstatus belum menikah, sedang bekerja, baik laki-laki maupun perempuan.

\section{Daftar Pustaka}

Bradutanu, D. (2012). Identifying The Reducing RTC Phase in an Organizational Change
Model. Acta Universitatis Danubius. Romania: Acta Universitatis Danubius.

Gunarsa, S. D. (2004). Psikologi Praktis Anak, Remaja dan Keluarga. Jakarta: PT. Gunung Mulia.

Khoirunnisa, N. R., Dewi, K. D., \& Nurwidawati, D. (2018). Pembelajaran E-Learning Perkembangan Anak Di Jurusan Psikologi. Jurnal Ilmu Sosial, Sains Dan Humaniora, 1(9), 199-211.

Naomi, P., \& Nindyati, D. A. (2007). Studi tentang Resistensi terhadap Perubahan Pada Kepuasan Kerja dari Dosen dan Staf Administrasi di UPM, Jakarta. Sosiohumanitas, 2(9), 133-148.

Nindyati, D. A. (2009). Pengaruh Resistance To Change Terhadap Perilaku Inovatif: Kecerdasan Emosi Sebagai Mediator. Jurnal Ilmiah Universitas Paramadina, 6.

Oreg, S. (2008). Dispositional Resistance To Change: Measurement Equivalance And The Link To Personal Values Across 17 nations. Journal of Applied Psychology, 4(93), 935 - 944.

Piderit, S. K. (2000). Rethinking Resistance and Recognizing Ambivalence: A Multidimensional View of Attitudes toward an Organizational Change. The Academy of Management Review, 25(4), 783. doi: $10.2307 / 259206$.

Putri, N. R. A., \& Handoyo, S. (2014). Perbedaan Resistensi Terhadap Perubahan Ditinjau Dari Generasi Kohort Dan Pemenuhan Kontrak Psikologis Pada Karyawan Pt. Telkom Area Surabaya Metro (Witel JatimSuramadu). Psikologi Industri Dan Organisasi, 3(1), 4121233-4121235. Retrieved from http//library.iyte.edu.tr/tezler/master/makina muh/T000703.pdf

Reagan, R. O. (2013). Emotion and E-Learning. Buletin JALN, 3(7), 78-92.

Robbin, S., \& Judge, T. A. (2008). Perilaku Organisasi (12th ed.). Jakarta: Salemba Empat. 
Utomo, W. P. (2019). Indonesia Millennial Report 2019. IDN Research Institute, 01, 61. Retrieved from https://www.idntimes.com/indonesiamillenn ialreport2019

Wulandari, D., \& Dwiyanti, R. (2014). Hubungan Konflik Peran Ganda Dan Stress Kerja Perawat Wanita di RSUD Banyumas. Jurnal Psycho Idea, 2(12), 33 - 41. 